\title{
VIEŠŲJŲ FINANSŲ UGDYMO ASPEKTAI SOCIALINIŲ EKONOMINIŲ POKYČIŲ KONTEKSTE
}

\author{
Prof. dr. Gediminas Dubauskas \\ Generolo Jono Žemaičio Lietuvos karo akademija
}

\begin{abstract}
Anotacija. Viešieji finansai ir pinigu politikos samprata yra svarbi ir universali kiekvienos šalies bendruomenès ugdymo sritis. Šios socialiniu mokslu disciplinos daro ịtaka šalies raidai ir atskiru piliečiu gyvenimui. Todèl daugelyje valstybiu piliečiams ugdyti pasitelkiamos ir viešuju finansu suvokimo studijos kaip būdas pagrịsti pilietiškuma. Straipsnyje iškeliamos ir nagrinejjamos šios temos ir mokslinès problemos - viešuju finansu valdymo, kaip svarbios pilietiškumo ugdymo studiju dalies, reikšmingumas, - dirbančiuju sumokamu mokesčiu dydis ir reali mokestine našta. Taip pat aptariamas studentu ir kariūnu finansinis ugdymas socialiniu mokslu krypties programose. Dvidešimt pirmojo amžiaus pradžioje mokesčiu ir viešuju finansu tematika tampa vis labiau aktuali, dèl nuolatinès ịtampos visuomenèje didinant mokesčius (ir mokesčiu našta), dèl dažno valstybès biudžeto deficito ir viešuju finansu suvokimo tiesioginès naudos bendram pilietiškumo ugdymo plètojimui.

Vienas iš galimu būdu spręsti asmeniniu finansu ir ekonominiu sąlygu pokyčiu poveiki yra universitetiniu studiju finansinio ugdymo programos. Tokiu finansinio ugdymo programu plètra padeda igyvendinti ir pagerinti kariūnu ir studentu mokymosi patirtị ir suvokti viešujų institucijų veikima ir pačių kariūnu indèlị ị šalies plètra. Taigi šio straipsnio vienas iš uždaviniu yra atskleisti, kad mokesčiai yra piliečiu bendrumo su ju valstybe aiškiausiai suvokiamas santykis. Be to, publikacijoje bandoma atsakyti $i$ klausimus apie finansinio ir ekonominio ugdymo svarba, pateikiant dirbančio piliečio mokesčiu naštos dydị ir jo skirtumus lyginant su viešu instituciju pateikiamais duomenimis.

Tai liečia gyventoju pajamu mokesčio, socialinio draudimo ir sveikatos draudimo mokesčiu dydžius. Deja, šioje srityje galimas ir neatitikimas, nes yra skirtingai interpretuojami „, Sodros “ ir privalomojo sveikatos draudimo fondo mokesčiai ar ịmokos. Dèl nagrinéjamu esamu netiesioginiu mokesčiu daromos prielaidos, kaip, pavyzdžiui, jau po tiesioginiu sumokètu mokesčiu vidutinès algos gavejas likusius pinigus išleidžia pirkdamas prekes ir paslaugas Lietuvoje ir vèl sumokèdamas netiesioginius mokesčius jau iš grynuju (neto) pajamu. Tokie palyginamai galimai nèra tikslūs, bet ju paklaida yra gana maža remiantis apklausų rezultatais. Pateikiami oficialūs ir tik su darbo santykiais arba jų esmę atitinkančiais santykiais susijusiu pajamu skirtingi mokesčiu naštos dydžiai Europos Sajungos šalyse.
\end{abstract}

Pagrindiniai žodžiai: ugdymas, viešieji finansai, mokesčiai, ekonomika, biudžetas, mokesčiu našta. 
Ivadas. Finansų ir pinigų istorinè ir reali samprata ugdymo procese yra viena svarbiausių ekonominio ir finansinio rengimo dalių. Pinigų tema visiems galimai suprantama, bet turinti nemažai sudètingų aspektų, tiek nuolatinès rinkos ekonomikos kaitos, tiek istoriniais pinigu kilmès ir pinigu ar pinigu politikos aspektais. Kiek reikia tokių žinių siekiant aukštojo universitetinio išsilavinimo? Todėl galbūt kiekvienoje universitetinių studijų mokslo kryptyje turètų būti dèstomi finansų ugdymo dalykai. Beje, mokestineje ir biudžeto sandaros terminologijoje asmens gaunamos pajamos tik iš darbo santykių yra vadinamos su darbo santykiais arba jų esmę atitinkančiais santykiais susijusiomis pajamomis.

Problema. Savivaldybès pagal pilietiškumo ugdymą yra pirmoje vietoje kasdieniuose jų santykiuose su piliečiais, mokesčių mokètojais. Bet savivalda, kaip ir valstybès institucijos, nuolat bando padidinti mokesčių bazę ir dažnai reikalauja mokèti už paslaugas, kurias turètų suteikti nemokamai, tai yra už jau surinktus nemažus mokesčius. Informacija apie vietos valdžios išlaidas turi būti prieinama visiems, įskaitant smulkias sudedamąsias dalis, ir galbūt su komentarais apie tų mokesčių panaudojimo tikslingumą. Skirtingai nuo valstybès įstatymų leidybos, tai yra Seimo, kuris yra iš dalies izoliuotas nuo šiu pastabų apie kasdienes išlaidas, savivaldos vietos valdžios institucijų sąnaudos turi būti matomos. Savivaldos išlaidų nagrinèjimas teoriškai yra esminis, kai bandoma išspręsti pagrindines problemas; padidinti mokestinę bazę, kurti darbo vietas ir išlaikyti gyvenimo kokybę tos savivaldybès bendruomenejje. Deja, Lietuvos savivaldos samprata yra menkai suprantama tiek viešujų i̊staigų tarnautojų, tiek iš juos išlaikančių mokesčių mokètojų.

Tyrimo tikslas - atskleisti kariūnų ir studentų finansų valdymo suvokimo lygi, viešojo administravimo suvokimo finansinius aspektus ir išsiaiškinti mokesčiu naštos suvokimo lygi.

Tyrimo objektas - Generolo Jono Žemaičio Lietuvos karo akademijos kariūnų ir studentų finansinių (ir iš dalies ekonominių) dalykų suvokimas, paremtas viešųų finansų ir mokesčių naštos teorijomis.

Tyrimo uždaviniai: Apžvelgti finansų ir viešųų finansų ugdymo tematiką mokslinejje literatūroje. Atskleisti vyraujantį kariūnų ir studentų viešųų finansų ir mokesčiu naštos suvokimą. Straipsnio vienas iš esminių uždavinių yra atskleisti, kad mokesčiai yra piliečių aiškiausiai suvokiamas bendrumo su jų valstybe santykis. Be to, straipsnyje bandoma atsakyti ị klausimus apie finansinio ir ekonominio ugdymo svarbą, pateikiant dirbančio piliečio mokesčių naštos dydį, ir jo skirtumus lyginant su viešųų institucijų pateikiamais duomenimis. Atlikti Lietuvos ir kitu Europos Sajungos šalių mokesčiu naštos analizę, išskiriant oficialiai pateikiamus duomenis ir realią dirbančių asmenų sumokamų mokesčių dalį.

Tyrimo metodai ir metadologija. Tyrimui buvo pasitelkta literatūros analizè, kokybiniai ir kiekybiniai tyrimo metodai, surinkti Lietuvos ir kitų ES šalių finansinių ir kitų institucijų duomenys. Taip pat remtasi įvairaus amžiaus dieninių ir ištęstinių studijų kariūnų ir studentų neformalių apklausų rezultatais. Pateikti pre- 
liminarūs kiekybiniai galimų piliečių gautų pajamų, susijusių su darbo santykiais, išlaidų Lietuvoje skaičiavimai. Taip pat galima paminèti autoriaus surinktus duomenis daug metų dėstant viešųjų finansų valdymą, rengiant straipsnius ir mokymo priemones. Šiame straipsnyje esantys tiesioginių mokesčių duomenys yra paimti iš oficialių Statistikos departamento ir Valstybinès mokesčių inspekcijos šaltinių.

\section{Finansų samprata ugdymo procese}

Itin svarbūs viešieji finansai, ankstesniais laikais, dažnai vadinti valstybès finansais, nes mokesčių naštos nagrinèjimas buvo antraeilis dalykas kuriant socialistinę ekonomiką. Deja, tokios nuostatos dažnai išlieka ir daugelio dabartinių darbuotojų ir studentų sampratose. Taip pat, esmingiausios visos šalies ekonomikos problemos beveik visuomet susijusios su korupcijos ir neskaidrios veiklos atvejais (Aarma 2012), kurie ir yra dažniausi viešujų finansų srityje. Universitetų studentai dažnai rimtai nesuvokia rizikų priimant ne visuomet prasmingus finansinius sprendimus. Tenka pripažinti, kad bendrosios ne finansų ar ekonomikos specialybès studentų finansų srities žinios gerèja labai lètai (Dorothy 2012).

Bendruoju atveju viešujų finansų samprata ugdymo procese prasideda nuo mokesčių ir biudžeto sąvokų (Jurgutis 1995). Kaip pavyzdys pateikiamos savivaldybių mokesčių ir biudžeto struktūros, kurios turètų būti arčiausia kiekvieno šalies piliečio. Kita vertus, tai daugiau tinka vyresnio amžiaus studentams, kaip ištęstinių studijų ar magistro studijų programų dalyviams. Bakalauro studijų programose daugelis studentų pradejję studijuoti tuojau po vidurinio mokslo yra mažiau susipažinę su savivaldos, o juo labiau valstybès biudžetais, ir juos pildančiais mokesčiais. Šiuo požiūriu finansinis ugdymas igyja didesnę prasmę, taip pat pradedamas suvokti valstybės vaidmuo ekonomikoje. Atsiranda galimybė susipažinti su valstybės ekonomikos reguliavimo funkcijomis (kaip perskirstymo funkcija), socialine funkcija ir kontroless funkcija (Dubauskas 2013). Finansiniam ugdymui taip pat svarbu Lietuvos valstybės ir savivaldybių pajamos ir išlaidos, pajamų struktūra, pagrindiniai i̊statymai, kuriais vadovaujantis renkami mokesčiai ir skirstomi asignavimai.

Mokesčiu suvokimas dažnai yra gana sudètingas, nes lietuvių kalboje vartojamas tas pat mokesčiu terminas ir viešojo sektoriaus mokesčiams, už kuriuos tiesiogiai nieko negaunama, ir mokesčiams už konkrečias paslaugas. Todèl terminų painiojimas yra dažniausiai pasitaikanti klaida, kuri patvirtina, kad būtinas viešujų finansų dèstymas visų studijų krypčių programų studentams ir kariūnams.

Dažniausiai oficialiai nurodoma, kad dvidešimt pirmojo amžiaus pirmajị dešimtmetį Lietuvos ūkio mokesčiu našta buvo apie 29 nuošimčius nuo šalies bendrojo vidaus produkto (1 pav.). Dèl to dažnai politikų ir ekspertų vis svarstoma, kad galbūt reikia didinti Lietuvoje mokesčių naštą, nes ji dar nèra pakankamai didelè. Tačiau pamirštama, kad socialinio draudimo įmokos ir privalomojo sveikatos draudimo įmokos ị atitinkamus fondus nèra priskiriamos fizinių ir juridinių asmenų mokesčių naštai. Jos dažniausiai vertinamos kaip draudimo įmokos. Bet analizuodami 
privačių sveikatos ir socialinio draudimo fondų veiklos aspektus matome tam tikrų skirtumų tarp privačių ir viešų draudimo fondų. Tokiu atveju visiems žinoma, kad įmoka ị „Sodrą“ yra 34 nuošimčiai ir įmoka ị Privalomajị sveikatos draudimo fondą (PSDF) yra 6 nuošimčiai nuo visų gautų neatskaičius mokesčių pajamų (Lietuvos Respublikos 2015 metų valstybès biudžeto ir savivaldybių biudžetų finansinių rodiklių patvirtinimo įstatymas, 2015). Prideję šiuos skaičius prie pateikiamos mokesčių naštos (pavyzdžiui, 32 nuošimčių) jau gauname kitus skaičius. Bendrai šalies ūkiui tai būtų apie 50-55 nuošimčiai ir beveik prilygtų skandinaviškai mokesčių naštai, kuri yra didžiausia ES ir viena didžiausių pasaulyje. (O pajamas gaunantiems tik iš darbo santykių tokia našta gali sudaryti ir apie 70 nuošimčių.)

\section{Mokesčių našta kalbant apie viešuosius finansus}

Taigi fiziniams asmenims, gaunantiems su darbo santykiais arba jų esmę atitinkančiais santykiais susijusias pajamas, tokia mokesčių našta sudarys tikrai daugiau nuošimčiu (De Haan et al. 2002). Panagrinėsime viešųų finansų sampratos ugdymo aspektus. Jei vidutinis Lietuvos darbo užmokestis neatskaičius mokesčiu (bruto) yra 700 euru (Lietuvos statistikos departamentas, 2015), darbdaviui tokios darbo vietos kaina $700+218,86$ eurų, nes 30,98 procento nuo darbo užmokesčio neatskaičius mokesčiu (arba bruto) yra pervedama ị „Sodrą" ir dar darbdavio ịmokos ị garantinį fondą sudaro 0,2 nuošimčio (mūsų atveju tai būtų 1,4 euro). Taip nerodoma papildoma suma darbdaviui sudaro 218,86 euro. Taigi viena darbo vieta per mènesi kainuoja 918,86 euro. Dažnai oficialiai pateikiama būtent tokia darbo vietos kaina darbdaviui. Taigi tokia suma reikalinga, kad darbuotojas gautų 700 eurų mènesinị atlygị neatskaičius mokesčių. Bet atskaičius mokesčius darbuotojo atlyginimas bus 540,91 euro. Taip pat iš daugelio neformalių apklausų aiškejja, kad daugeliui visai nesvarbu, koks yra atlygis neatskaičius mokesčių. Tai patvirtina, kad nesuvokiama mokesčių našta. Tęsiant toliau mūsų analizę, jau nuo šios darbo sutartyje numatytos sumos mokami mokesčiai, kurie priskiriami oficialiai mokesčių naštai: „Sodrai“ trys nuošimčiai nuo pirmo atlyginimo euro, nes neapmokestinamasis pajamų dydis šiuo atveju netaikomas, šeši nuošimčiai pervedami ị Privalomojo sveikatos draudimo fondą ir 15 nuošimčių gyventojų pajamų mokestis (GPM), kuriam priklausomai nuo gaunamų pajamų lygio ar dydžio taikomas neapmokestinamasis pajamų dydis (NPD). Reiktų pažymèti kad NPD jau netaikomas gaunantiems 929 eurų atlyginimą neatskaičius mokesčių. Po 2008 metų gruodžio mènesio Lietuvos Seime priimtų reformų atejus globaliai finansų krizei ménesinis neapmokestinamasis pajamų dydis taikomas tik su darbo santykiais arba jų esmę atitinkančiais santykiais susijusioms pajamoms (darbo užmokesčiui, priedams, priemokoms). Mokestiniu laikotarpiu taikomas mėnesio NPD apskaičiuojamas atsižvelgiant tik ị pagrindinị darbo užmokesti, priedus ir priemokas. Jis skaičiuojamas pagal šią formulę:

Mènesio NPD $=166-0,26 \times$ (gyventojo mènesio su darbo santykiais arba ju esmę atitinkančiais santykiais susijusios pajamos - 290). Kai pagal pateiktą formu- 
lę apskaičiuotas NPD yra neigiamas, laikoma, kad jis lygus 0. (VMI, 2015)

Taigi iš darbo vietos kainos darbdaviui 918,86 euru yra mokama 55,18 nuošimčio mokesčių. Kadangi tokiam atlyginimui (700 eurų) dar yra taikomas NPD, šiuo atveju 59,4 euro, tai šią sumą reikia atimti iš 700 eurų skaičiuojant gyventojų pajamų mokesčio dydi, todèl nuo vidutinio mènesinio atlyginimo gyventojų pajamų mokestis yra 13,73. Taigi bendrai nuo darbo vietos kainos bus sumokama 53,91 nuošimčio mokesčių, arba 495,36 euro, o pačiam dirbančiajam (mokesčių mokètojui) lieka 423,5 euro. Tai sumokami tiesioginiai mokesčiai nuo darbo vietos kainos (918,86 eurų) darbdaviui, arba iš to, ką galètų gauti dirbantysis.

Darant prielaidą, kad tokio vidutinio darbo užmokesčio gavejjas visą savo mènesio uždarbị išleidžia prekèms ir paslaugoms Lietuvoje, jis vidutiniškai netiesiogiai dar sumoka pridètinès vertès mokestị ( 21 proc.), tai sudaro 88,94 euro, o asmeniui lieka 334,57 euro, arba 36,4 proc. nuo jo atlyginimo. Bet 36,4 proc., arba 334,57 euro suma (iš 918,86 euru), kurios paskirstymą pilietis gali pats valdyti, dar nesibaigia viešujų finansų poveikis asmeniui - dar yra akcizo mokesčiai, gamtos išteklių mokesčiai, savivaldybès rinkliavos, kuriuos galima sąlygiškai vadinti netiesioginiais mokesčiais. Žemès, nekilnojamojo turto, paveldèjimo mokesčiai yra tiesioginiai mokesčiai, apie kuriuos reiktų irgi kalbèti.

Iš visų paminètų kitų mokesčių, be abejo, vienas iš svarbesnių netiesioginių mokesčiu yra akcizo mokestis, taikomas naftos produktams, elektros energijai, alkoholiui ir tabakui (Hyman 2014). Priklausomai nuo vartojimo krepšelio ir turint galvoje, kad akcizo mokestis dažnai sudaro iki pusès prekès kainos, likusių 334,6 euro dar galime atskaičiuoti mokesčiams apie 10 proc., arba 33,5 euro. Tada piliečio laisvai disponuojama pinigų suma jau sudaro 301 euro, arba 32,77 proc. nuo darbo užmokesčiui skirtos sumos.

Dar nereiktų pamiršti ir žemės, nekilnojamojo turto mokesčių ir savivaldybių rinkliavų, anksčiau vadintų žyminiais mokesčiais. Galimai nemaža dalis Lietuvos piliečių yra žemès savininkai. Taigi jiems prisideda dar vienas mokestis. Dar didesnè dalis yra nuosavų būstų savininkai - apie 85 proc. Lietuvos namų ūkių yra nuosavuose butuose ar namuose. Taigi nuo likusio 301,07 euro mokesčiams dar reiktų skirti kelis proc. Prie to dar pridejus perkamų, importuotų i ES prekių, muitų mokesčius papildomai susidarytų galbūt apie penkis proc. Tai sudaro dar 15 eurų ir darbo užmokesčio gavejjas jau gali tvarkyti tik 285 eurus, arba 31 procentą jam skirtų finansų. Taigi pajamas gaunantiems iš su darbo santykiais arba jų esmę atitinkančiais santykiais susijusios veiklos mokesčių našta Lietuvoje sudaro apie 70 proc. Kartais tai dar vadinama darbo apmokestinimu. Šiame kontekste galima paminèti Laisvès nuo mokesčių dieną. Laisvès nuo mokesčių dieną vidutinis mokesčių mokètojas nustoja dirbti valstybei ir pradeda dirbti sau. Straipsnyje aprašomais metais visos Lietuvos juridiniams ir fiziniams asmenims Laisvès nuo mokesčiu diena Lietuvos laisvosios rinkos instituto buvo paskelbta gegužès 15 diena (LLRI, 2015).

Nors pagal fondo „Naujoji kryptis - Europos reformu““ kartu su Molinari 
ekonomikos institutu naudojant bendrą metodiką atliktą tyrimą visose 28 ES šalyse atsisveikinimo su mokesčiais datos 2014 metais buvo tokios: kovo $21 \mathrm{~d}$. Kipras, balandžio 28 d. Airija ir Malta, gegužès 12 d. Jungtinè Karalyste, gegužès 18 d. Bulgarija, gegužès 30 d. Liuksemburgas, birželio 6 d. Portugalija, birželio 7 d. Danija, birželio $8 \mathrm{~d}$. Slovenija, birželio $10 \mathrm{~d}$. Estija, birželio $12 \mathrm{~d}$. Ispanija, birželio $13 \mathrm{~d}$. Kroatija, birželio $14 \mathrm{~d}$. Lenkija, birželio $18 \mathrm{~d}$. Lietuva, birželio $19 \mathrm{~d}$. Čekija, birželio 20 d. Suomija, Slovakija ir Latvija, birželio 21 d. Nyderlandai, birželio $23 \mathrm{~d}$. Švedija, birželio $30 \mathrm{~d}$. Italija, liepos $1 \mathrm{~d}$. Rumunija, liepos $11 \mathrm{~d}$. Vokietija, liepos $14 \mathrm{~d}$. Graikija, liepos $16 \mathrm{~d}$. Vengrija, liepos $25 \mathrm{~d}$. Austrija, liepos $28 \mathrm{~d}$. Prancūzija, rugpjūčio $6 \mathrm{~d}$. Belgija (Tax Burden for Typical Workers in the EU, 2014).

Tačiau laisvès nuo mokesčių diena pajamas gaunantiems tik iš darbo santykių arba jų esmę atitinkančių santykių Lietuvoje galbūt yra rugpjūčio 15 d. Gal ir neatsitiktinai ji sutampa su senaja švente. Taigi šiuo atveju remiantis fondo „Naujoji kryptis - Europos reformų“ 2014 metų tyrimais netgi aplenkiama Belgija, kurioje laisvès nuo mokesčiu diena yra rugpjūčio $6 \mathrm{~d}$. Be abejo, reiktų pastebèti, kad minètame tyrime galbūt nèra skaičiuojami mokesčiai, sumokami perkant ir vartojant jau po tiesioginių mokesčių, atskaičiuotų nuo atlyginimo. Nuo tos dienos pradedame dirbti sau, o iki tol dirbame kad sumokètume mokesčius, be kurių, aišku, negalètu egzistuoti ir valstybė. Tačiau panaudojant dirbančių mokesčių mokètojų 70 proc. lèšų skaidrumas yra būtinas, tačiau vis dar nepakankamas. Taigi mokesčių naštos apžvalgos pagrindu buvo pateiktas viešųjų finansų sampratos ugdymo būtinumas. Ne mažiau svarbus yra ir asmeninių finansų supratimas bei pasaulio ir Lietuvos pinigų raida. 


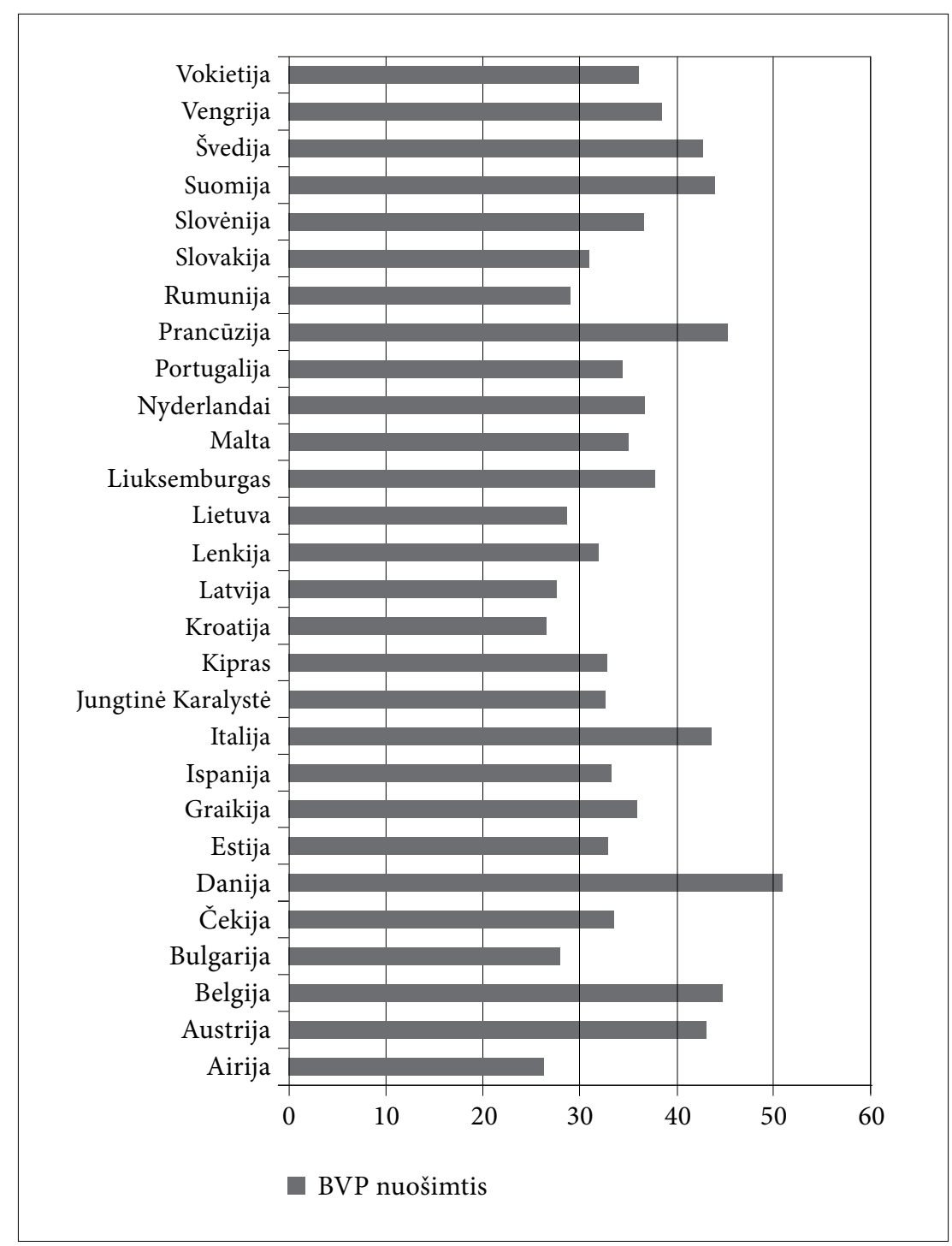

1 pav. Oficialiai skelbiama mokesčių našta įvairiose Europos Sajungos šalyse (2013-2014 m. nuošimčiais nuo bendrojo vidaus produkto)

Šaltinis: Taxation Trends in the EU; 2014, AMECO database - spring 2013, p. 2-12 OECD Economics Department Working Papers, Total Tax Revenue by Country, 2014, p. 3-4 


\section{Išvados}

Kaip jau buvo aptarta daugelyje Europos Sajungos, o ir kitu pasaulio šalių, ugdymo procese gana svarbūs bendrajam piliečių ugdymui yra finansų žinių tobulinimo ir lavinimo aspektai. Tai itin aktualu aukštojo mokslo institucijose finansu žinias siejant su atitinkamomis aukštojo mokslo studijų ir mokslinių tyrimų programomis. Dažnai viešųjų finansų administravimo ir ịvairių ugdymo programų sąsajos atskirose programose vertinamos skirtingai. Kai kuriose aukštosiose mokyklose socialinių mokslų atstovai vis dar diskutuoja, ar finansų valdymas ir ypač viešųjų finansų administravimas gali būti laikomas svarbia ugdymo mokslo ir studijų šaka, tačiau pastaraisiais dešimtmečiais vis labiau ịsigali nuostata, kad tokia diskusija neduoda tiesioginès naudos. Dėstant viešuosius finansus, kartais Vidurio ir Rytų Europoje dar vadintus valstybès finansais, pavyzdžiu galima ugdyti savo šalies patriotus ir asmenis, nepakančius neskaidriems reiškiniams. Labai dažnai geriausias piliečio dalyvavimas savo šalies valdyme yra mokesčių, skirtų svarbiausioms valstybės funkcijoms atlikti, mokejjimas. Vienas iš būdu nustatyti šalies bendrų ar konsoliduotų mokesčių dydị fiziniams ir juridiniams asmenims yra mokestinès naštos rodiklis. Kadangi tokie duomenys centrinei Europos statistikos institucijai pateikiami nacionalinių statistikos departamentų ar biurų, jie dažnai atspindi tos šalies požiūrị ị mokesčių naštos skaičiavimą. Taigi pagal oficialius duomenis $2014 \mathrm{~m}$. Lietuvos mokesčių našta yra gana maža $-28,7$ proc. nuo bendrojo vidaus produkto, bet apskaičiuojant mokesčiu naštą galima paklaida dèl socialinių ir sveikatos įmokų, kurios interpretuojamos gana skirtingai. Dar svarbesnis yra eilinio piliečio, gyvenančio iš su darbo santykiais arba jų esmę atitinkančiais santykiais susijusių pajamų. Tada jau tiesioginių mokesčiu našta beveik dvigubai viršija oficialiai pateikiamą šalies mokesčių naštą. O ịskaitant kitus, kartais vadinamus paslëptais, mokesčius, susijusius su vartojimu, dirbančiojo mokesčių našta artėja prie dviejų trečdalių visų su darbo santykiais susijusių pajamų. Šiuo požiūriu Laisvès nuo mokesčių diena eiliniam dirbančiajam nusikelia ị antro metų pusmečio pradžią. Toks mokesčių naštos suvokimas galbūt tikrai paskatins kiekvieną pilietị atsakingiau žiūrèti ị viešojo sektoriaus tarnautojų vykdomus darbus ir biudžeto planavimo procesus, aktyviau dalyvauti politiniame gyvenime, darant prielaidą, kad procesai vyksta skaidriai. 


\section{Literatūra}

1. Aarma, A.; Dubauskas, G. (2012). The Foreign Commercial Banks in the Baltic States: Aspects of the Financial Crisis Internationalization. European Journal of Business and Economics, Vol 5. DOI:http://dx.doi.org/10.12955/ejbe.v5i0.161.

2. De Haan, J.; Sturm, J. E.; Volkerink, B. How to Measure the Tax Burden on Labour. Paper presented at the CESifo Conference on Measuring the Tax Burden on Labour and Capital, Venice, July 2002.

3. Dubauskas, G. (2013). Ekonomikos ir finansų teorijos. Vilnius.

4. Durband, D. B.; Britt, S. L. (2012). Student Financial Literacy: CampusBased Program Development. Springer Science \& Business Media.

5. Hyman, N. D. (2014). Public Finance: A Contemporary Application of Theory to Policy. Cengage Learning, Stamford.

6. Jurgutis, V. (1995). Finansų mokslo pagrindai. Vilnius.

7. Lietuvos Respublikos 2015 metų valstybès biudžeto ir savivaldybių biudžetų finansinių rodiklių patvirtinimo įstatymas. [žiūrèta 2015-12-08]. Prieiga per internetą: www3.lrs.lt/docs2/HAFBWWSU.PDF.

8. Lietuvos Respublikos Statistikos departamentas. Darbo užmokesčio indeksai, darbo užmokestis. [žiūrèta 2015-11-02]. Prieiga per internetą: http://osp. stat.gov.lt/web/guest/statistiniu-rodikliu-analize?portletFormName=visualization \&hash=845d6bd4-643f-4192-96d1-c34f9be492aa.

9. LLRI, 2015. [žiūrèta 2015-11-25]. Prieiga per internetą: http://www.llri.lt/ projektai/faktai-ir-analize.

10. OECD Economics Department Working Papers, Total Tax Revenue by Country. (2014).

11. Tax Burden for Typical Workers in the EU. New Direction - The Foundation for European Reform, Brussels, Belgium. (2014).

12. Taxation Trends in the EU, Data for the EU Member States, Iceland and Norway. Eurostat Statistical Book. (2014).

13. Tax Revenue as Percentage of GDP by Country. The World Bank Report. (2015). [žiūrèta 2015-12-02]. Prieiga per internetą: <http://www.apa.org/journals/ jwebref.html $>$ http://data.worldbank.org/indicator/gc.tax.totl.gd.zs?page $=1$

14. Valstybinè mokesčių inspekcija (VMI). [žiūrèta 2015-12-02]. Prieiga per internetą: https://www.vmi.lt/.../menesinio-neapmokestinamojo-pajamu-dydzioska... . 


\title{
THE ASPECTS OF FINANCIAL EDUCATION IN THE CONTEXT OF SOCIAL ECONOMIC CHANGES
}

\author{
Prof. Dr. Gediminas Dubauskas \\ The General Jonas Žemaitis Military Academy of Lithuania
}

\section{Summary}

Public finance and monetary policy conceptions are important to each country's higher education. It affects public sector, country's development and the lives of individual citizens. Therefore, a significant focus on the general development of public financial management and training methods is increasing. Moreover, the process is organized in connection with relevant higher education and research programs. On the other hand, financial management education is treated differently in different countries. In some countries social scientists are still debating whether public financial management can be seen as an important educational and scientific branch of study. It is becoming an increasingly important provision that such a discussion has not directly benefited from common development of financial education in recent years.

University and college students are often vulnerable and are not always meaningful in making their financial decisions. One of the possible ways to deal with personal finances in different economic conditions is to change the attitude of teaching students finance in higher education and universities. Young people must be supported by financial education programs that are in the best way incorporated into their underground study courses. The development of a program presents effective strategies to help implement and improve students' learning experience and economic well-being by developing their financial literacy. Such a program could present the main components of financial education in addressing growing concerns associated with high levels of debt and low levels of financial literacy issues. As has been discussed in a number of European Union and other countries, the process of education of some importance to the general civic education is to improve financial knowledge and education aspects. The learning based on public finances (in Central and Eastern Europe it has been called state finances) educates patriots of their country and people intolerant to nontransparent activities of public servants.

Very often the best citizens' participation in the governance of their country is paying taxes for essential state functions. One of the best ways to determine country's consolidated taxes paid by natural and legal persons is the tax burden rate. Besides, the data is supplied to the central European statistics authority EUROSTAT by national statistical offices. Meanwhile, the approaches to the data are often reflected in a country's position regarding the calculation of the tax burden. Thus, according to official figures, Lithuanian tax burden rate was relatively low in 2014 , i.e. approximately 28.7 per cent of the Gross Domestic Product. Nevertheless, the statistical data can be biased due to the evaluation of social and health contributions, which are interpreted quite differently. Even more important is that an ordinary citizen living from income related to labor relations (or corresponding relations to income) has much higher tax burden. Then we have a direct tax burden increase by almost twice versus officially presented national tax burden. However, additional tax burden includes hidden taxes related to the use by an average employee probably all his/ 
her income inside the EU. Then the tax burden for an employee approaches two-thirds of all the work-related incomes. In the sense of "the freedom from taxes day", the date moves to the second half of the year for an ordinary worker. This perception of the tax burden can encourage every citizen to be responsible for public servants' operations and budget planning processes. It requires greater involvement in a political life assuming that the processes take place in a transparent manner.

\section{AUTORIAUS LYDRAŠTIS}

Autoriaus vardas, pavardè: Gediminas Dubauskas

Mokslo laipsnis ir vardas: daktaras, profesorius

Darbo vieta ir pareigos: Generolo Jono Žemaičio Lietuvos karo akademijos Vadybos katedros profesorius

Autoriaus mokslinių interesų sritys: vadyba, finansai, ekonomika, edukologija

Telefonas ir el. pašto adresas: 867279 858; gediminas.dubauskas@lka.lt

\section{AUTHOR'S COVER LETTER}

Author's name and surname: Gediminas Dubauskas

Academic degree and name: Doctor, Professor

Workplace and position: The General Jonas Žemaitis Military Academy of Lithuania, Department of Management

Author's research interests: management, finance, economics, education

Telephone and e-mail address: +370672 79 858; gediminas.dubauskas@lka.lt 